Article

\title{
In Vitro Characterization of Indigenous Probiotic Strains Isolated from Colombian Creole Pigs
}

\author{
César Betancur ${ }^{1}$, Yordan Martínez ${ }^{2} \mathbb{B}$, Guillermo Tellez-Isaias $\left.{ }^{3} \mathbb{(}\right)$, Mavir Carolina Avellaneda ${ }^{2} \mathbb{C}$ \\ and Borja Velázquez-Martí ${ }^{4, *}$ (D) \\ 1 Departamento de Ciencias Pecuarias, Facultad de Medicina Veterinaria y Zootecnia, \\ Universidad de Córdoba, Montería 230002, Colombia; betanci@yahoo.com \\ 2 Science and Agricultural Production Department, Zamorano University, \\ Francisco Morazán P.O. Box 93, Honduras; ymartinez@zamorano.edu (Y.M.); \\ cavellaneda@zamorano.edu (M.C.A.) \\ 3 Department of Poultry Science, University of Arkansas, Fayetteville, AR 72701, USA; gtellez@uark.edu \\ 4 Departamento de Ingeniería Rural y Agroalimentaria, Universitat Politècnica de València, \\ Camino de Vera s/n, 46022 Valencia, Spain \\ * Correspondence: borvemar@dmta.upv.es
}

Received: 9 June 2020; Accepted: 11 July 2020; Published: 15 July 2020

check for updates

Simple Summary: In the pig industry (mainly after weaning), enteric diseases are frequent associated with pathogenic bacteria such as Salmonella spp. and E. coli. Although the European Union has banned the use of growth-promoting antibiotics, many countries use these synthetic medications with widespread, which has led to an increase in the number of antibiotic-resistant pathogens, cross-resistance, and bioaccumulation in tissues. Probiotics are beneficial bacteria that live in the intestine and improve the host health; they are also one of the main alternatives to subtherapeutic antibiotics. Therefore, our goal was to obtain lactic acid bacteria from Colombian creole pigs that had never consumed a medicated diet and to carry out in vitro probiotic tests. Three strains lived before were identified: L. plantarum CAM6, L. plantarum CAM7 and L. plantarum CL4. The obtained strains have good activity in the physiological, antibacterial and antibiogram tests. Further studies to evaluate the efficacy of this strain in commercial pigs are currently being evaluated.

Abstract: Three lactic acid strains were isolated from feces of the native Zungo Pelado breed of pigs $(n=5)$ and presumably identified as belonging to the Lactobacillaceae family by morphological techniques showing that they were Gram-positive/rod-shaped and catalase- and oxidase-negative. They were then identified by biochemical tests using API 50CHL as Lactobacillus plantarum (CAM6), Lactobacillus brevis (CAM7), and Lactobacillus acidophilus (CL4). However, 16S rRNA identification showed that all three strains were Lactobacillus plantarum. Additionally, all three isolates were able to grow in $\mathrm{pH} 3$ and 4 . Interestingly, the growth of the CAM7 strain decreased at $\mathrm{pH} 5.6$ compared to that of the CAM6 strain $(p<0.05)$, and the growth of the CL4 strain was reduced at $\mathrm{pH} 7(p<0.05)$. All three candidates showed good growth on bile salts ( $\geq 0.15 \%)$, and CAM6 and CAM7 showed better tolerance at higher concentrations $(0.30 \%)$. Similarly, all strains tolerated sodium chloride $(\mathrm{NaCl})$ concentrations from 2 to $10 \%$. These strains also grew well at all temperatures tested $(30,37$, and $42{ }^{\circ} \mathrm{C}$ ). The CAM6 strain showed in vitro antibacterial activity against selected enteropathogenic bacteria (Escherichia coli strain NBRC 102203 and Salmonella enterica serovar Typhimurium 4.5.12) and commensal bacteria (Klebsiella pneumoniae ATCC BAA-1705D-5 and Pseudomonas aeruginosa ATCC 15442) and resistance to all antibiotics except amoxicillin. Further studies to evaluate the effects of these probiotic candidate strains in commercial pigs are currently underway.

Keywords: lactic acid bacteria; native pig; probiotic; Zungo Pelado 


\section{Introduction}

The indiscriminate use of antibiotics for disease prevention and as growth promoters in animal husbandry increases the number of antibiotic-resistant pathogens [1] and the risk that these resistant pathogens can be transmitted to humans [2]. Moreover, the presence of antibiotic residuals in meat products might pose a significant public health risk as, once consumed, antibiotic residuals might also increase bacterial resistance in humans [3]. Some of these pathogens have proven to be extremely resistant to all commonly used antibiotics and/or capable of rapidly developing resistance when exposed to antibiotic prophylaxis or treatment [4].

Antibiotics are generally ineffective in the treatment of multidrug-resistant bacteria. The incidence of foodborne pathogens, such as Salmonella spp., Escherichia coli, and Campylobacter spp., is increasing worldwide, with reports of antibiotic resistance in clinical isolates of these and other enteric pathogens [1]. The diminishing effectiveness of antibiotics-wonder drugs of the 20th century-has become a looming threat to public health. In response, on 1 January 2017, the United States Food and Drug Administration, working to ensure the judicious use of antibiotics in human medicine, restricted the employment of such antibiotics in growth promotion and expanded the list of feed-grade antibiotics classified as Veterinary Feed Directive drugs [5]. Equally concerning is the fact that indiscriminate use of antibiotics can induce disruption of the intestinal microbiome, reducing the production of short-chain fatty acids and increasing luminal $\mathrm{pH}$ in the distal gastrointestinal tract, which results in dysbacteriosis [6].

In recent years, substantial scientific evidence has shown that the use of certain antibiotics increases enteric colonization of antibiotic-resistant strains of enteric pathogens in domestic animals [7]. In the swine industry, enteric infections are frequent causes of diarrheal diseases and represent a serious health threat to the animals. Infections can occur at any point in their lifetime, but the highest incidence of disease occurs during certain critical times, which can be divided according to the production system into the suckling, weaning, and growing periods.

During the first week of life, piglets commonly encounter infections from Clostridium perfringens type A or enterotoxigenic E. coli [8,9]. To date, several compounds have been used as alternatives to antibiotics, such as organic acids, probiotics, prebiotics, and plant extracts. De Mille et al. [10], Chen et al. [11], and Julio-Gonzalez et al. [12] have demonstrated favorable results of the use of such alternatives in terms of both health and productivity [13]. However, a major strategic concern is the lack of knowledge of the mechanisms through which the alternative substances can protect intestinal cells from the damage induced by pathogens [14].

Still, recent global research has indicated the use of probiotics to be a promising alternative to antibiotic growth promoters $[15,16]$. The high acidity in the stomach and great concentration of bile components in the proximal intestine are the first host factors that may affect commercial probiotics $[6,17,18]$.

Although probiotics are commonly used, only in the last two decades have scientists discovered the physiological mechanisms behind the improvement in health and performance of animals in the meat production industry $[19,20]$. Several investigators have demonstrated the beneficial effects of probiotics, such as modulating the host's immune response (both the innate and adaptive response) [21], stimulating immunoglobulin production (Ig) (mainly IgA by B lymphocytes [22]), promoting the animal's response to external aggressors [23], exerting antioxidant properties [24], producing enzymes, and reinforcing the integrity of the intestinal barrier through the phosphorylation of proteins from the narrow unions of intestinal epithelium cells [25].

Many microorganisms have been used as probiotics, but lactic acid bacteria (LAB) have been shown to be the most effective probiotic agents in swine production $[1,6,26]$. Several studies confirm the beneficial effect of these bacteria on health and productivity in swine production $[27,28]$. In this sense, Wang et al. [29] showed that strains of Lactobacillus plantarum ZLP001 isolated from the gastrointestinal tracts of healthy pigs modulate their gut microbiota. As the natural microflora stabilizes in the gut easily, and quickly propagates to one specific species [27], an isolate from the host itself will be a more effective probiotic than isolates from other sources. 
The present study was conducted with the objective of phenotypically and phylogenetically characterizing the lactic acid bacteria isolated from the gastrointestinal tracts of the native Zungo Pelado breed of pigs in the northern coastal region of Colombia and for the in vitro evaluation of these strains as possible probiotic candidates that could be used as natural growth promoters to replace subtherapeutic antibiotics in swine production.

\section{Materials and Methods}

The present experiment was conducted in the Biotechnology Laboratory, Faculty of Sciences, GRUBIODEQ group of the University of Córdoba, Montería, Córdoba, Colombia.

\subsection{Bacterial Isolation}

Five pigs (Zungo Pelado) aged 6 months and weighing $55 \pm 5 \mathrm{~kg}$ were randomly selected from the AGROSAVIA Conservation Center, Cereté, Córdoba, Colombia. The pigs were fed commercial feed (without antibiotic growth promoters) and local agricultural byproducts, such as liquid processed feeds and feeds derived from the citrus and sugarcane industries. It is important to note that the veterinarian of the AGROSAVIA Conservation Center, Cereté, Córdoba, Colombia, certified that these pigs were apparently healthy since no symptoms, signs, or pathologies associated with any diseases were found and the blood and feces analyses were normal.

Stool samples were taken directly from the rectum with disposable gloves. Samples, in groups of three, were placed with ice packs in hermetic containers and transported to the laboratory. One gram of a sample from each pig was mixed with $9 \mathrm{~mL}$ of peptone water and shaken in a vortex mixer at $150 \mathrm{rpm}$ for $15 \mathrm{~min}$, and serial dilutions in sterile saline solution $0.9 \%$ were plated into de Man, Rogosa and Sharpe (MRS) agar plates (Catalog No. 288110, Becton Dickinson and Co., Sparks, MD, USA). Plates were incubated anaerobically (carbon dioxide atmosphere) for $48 \mathrm{~h}$ at $37^{\circ} \mathrm{C}$.

\subsection{Morphological and Biochemical Tests}

Individual isolates were tested for oxidase production, catalase, and Gram stain affinity. Colonial characteristics were observed on MRS agar, and cell morphology was observed with a microscope.

\subsection{Bacterial Identification}

The selected strains were initially identified using the API 50CHL medium and API 50CH, according to the manufacturer's instructions (BioMérieux, Marcy l' Étoile, France), and the results were interpreted by the software APIWEB (BioMérieux). The biochemical identification of each strain was confirmed by the sequencing of the $16 \mathrm{~S}$ rRNA gene. Genomic DNA was extracted from isolated colonies in MRS using a commercial Power Soil DNA Isolation Kit (QIAGEN, US), according to the manufacturer's instructions. The $1465 \mathrm{bp}$ region of the ribosomal gene $16 \mathrm{~S}$ was amplified by polymerase chain reaction (PCR) using universal primers F27 (5'-AGAGTTTGAT CMTGGCTCAG-3') and R1492 (5'-TACGGYTACCTTGTTACGACTT-3'), and its fragments were purified. Once purified, the products were sent to a reference laboratory for sequencing (Macrogen Inc., 2017, Seoul, Korea). The sequenced products were evaluated using the Basic Local Alignment Search Tool [30].

\subsection{Resistance under Gastrointestinal Conditions: Temperature, $p H$, and Sodium Chloride}

In this series of in vitro studies, a basal MRS medium was used. An overnight culture of each isolate was used as the inoculum. The cells were centrifuged and resuspended in $0.9 \%$ sterile saline. The three inoculums (100 $\mu \mathrm{L}$ each) were suspended in $10 \mathrm{~mL}$ of MRS agar in test tubes. The incubation timepoint was recorded at $24 \mathrm{~h}$ for evaluation of the variables ( $\mathrm{pH}$, sodium chloride $(\mathrm{NaCl})$, and temperature). The temperatures tested were 30,37 , and $42{ }^{\circ} \mathrm{C}$. The sodium chloride $(\mathrm{NaCl})$ concentrations were $2,4,7$, and $10 \%(w / v)$. The isolates were tested for survival at four $\mathrm{pH}$ levels: $3,4,5.6$, and 7 . The tubes were incubated with reciprocal shaking at $37^{\circ} \mathrm{C}$ for the $\mathrm{pH}$ and $\mathrm{NaCl}$ tests. The turbidity of each tube was 
determined by measuring optical density (OD) at $600 \mathrm{~nm}$ with a spectrophotometer (Spectrophotometer UV-1800; Shimadzu, Japan). Then, each isolate was streaked onto MRS agar to check for the presence or absence of growth in order to confirm the survivability of each strain. Each treatment was tested with triplicate tubes.

\subsection{Bile Salt Tolerance}

The method of Latorre et al. [31], with some modifications, was used to determine bile salt tolerance. The MRS agar tubes containing 0.05, 0.10, 0.15, or 0.30\% bile salts (Catalog No. 213010, Becton Dickinson and Co., Sparks, Maryland, USA) were inoculated with $10^{6} \mathrm{CFU} / \mathrm{mL}$ of each probiotic strain, after being centrifuged at $3000 \times g$ for $15 \mathrm{~min}$ and washed three times following overnight growth. Samples were incubated for $24 \mathrm{~h}$ at $37^{\circ} \mathrm{C}$ with shaking at $100 \mathrm{rev} . / \mathrm{min}$. Growth in control (no bile salts) and test cultures was evaluated at $24 \mathrm{~h}$ by streaking samples onto MRS agar for the presence or absence of growth.

\subsection{Assessment of Antimicrobial Activity against Enteropathogenic Bacteria}

The lactic acid isolates were screened for in vitro antimicrobial activity against Escherichia coli strain NBRC 102203, Salmonella enterica serovar Typhimurium 4.5.12, Klebsiella pneumoniae ATCC BAA-1705D-5, and Pseudomonas aeruginosa ATCC 15442. Ten-microliter aliquots of $10^{-6}$ to $10^{-7}$ dilutions of each tested isolate were placed in the center of MRS plates. After $24 \mathrm{~h}$ of incubation at $37^{\circ} \mathrm{C}$, the plated samples were coated with Tryptic Soy Agar (TSA) (Catalog No. 211822, Becton Dickinson, Sparks, MD, USA) containing $10^{6} \mathrm{CFU} / \mathrm{mL}$. After $24 \mathrm{~h}$ of incubation at $37^{\circ} \mathrm{C}$, the plates were evaluated and the colonies that produced zones of inhibition were selected.

\subsection{Antibiotic Susceptibility Testing}

Antibiotic susceptibility was determined using the disk diffusion method [32]. The probiotic candidate and pathogenic strains were subjected to different antibiotics commonly used to treat enteric and respiratory infections in swine production: ciprofloxacin $5 \mu \mathrm{g}$, dicloxacillin $1 \mu \mathrm{g}$, trimethoprim sulfamethoxazole $25 \mu \mathrm{g}$, amoxicillin $10 \mu \mathrm{g}$, tetracycline $30 \mu \mathrm{g}$, and doxycycline $5 \mu \mathrm{g}$. The individual strains were inoculated into MRS agar plates, and the pathogenic strains were inoculated into Mueller-Hinton agar plates for the antibiotic susceptibility test. After inoculation, the antibiotic disks were placed onto the surface of the cultures. All plates were incubated at $37^{\circ} \mathrm{C}$ for $24 \mathrm{~h}$ under microaerophilic conditions. After incubation, the diameter of the zone of inhibition was measured. A diameter of $\geq 21 \mathrm{~mm}$ indicated a susceptible (S) strain, a diameter of 16-20 mm indicated an intermediate (I) strain, and a diameter $\leq 15 \mathrm{~mm}$ indicated a resistant (R) strain [33].

\subsection{Data and Statistical Analysis}

Variance analyses were performed to verify significant differences between the means with a significance level of $p<0.05$. The Duncan test was used to describe the differences between strains $(p<0.05)$. All statistical analyses were completed using SPSS software (SPSS Inc., IBM Corporation, Version 22, Chicago, IL, USA). The counts of viable microorganisms were transformed to Log $\mathrm{N}$ to ensure normal conditions in the growth curve.

\section{Results}

\subsection{Morphological and Biochemical Tests of the Lactic Acid Bacteria Isolates}

All three isolated strains were Gram-positive microorganisms with rod morphology, occurring singly or grouped in short chains, with catalase- and oxidase-negative characteristics of lactic acid bacteria. API 50CHL identification provided a different name for each of the three selected strains: Lactobacillus plantarum for CAM6, L. brevis for CAM7, and L. acidophilus for CL4 (Table 1). However, $16 S$ rRNA identification showed that all three strains were Lactobacillus plantarum (Figure 1). 
Table 1. Comparisons between biochemical (API 50CHL) and 16S rRNA sequencing of the lactic acid bacteria isolates from the native Zungo Pelado breed of pigs.

\begin{tabular}{ccc}
\hline Bacterial Strains & API 50 CH & GenBank Accession and URL \\
\hline CAM6 & Lactobacillus plantarum & MK523644.1; URL: https://bit.ly/2t4cHC9 \\
CAM7 & Lactobacillus brevis & MK537353.1; URL: https://bit.ly/2MPnwzd \\
CL4 & Lactobacillus acidophilus & MK523645.1; URL: https://bit.ly/2tXJSYC \\
\hline
\end{tabular}

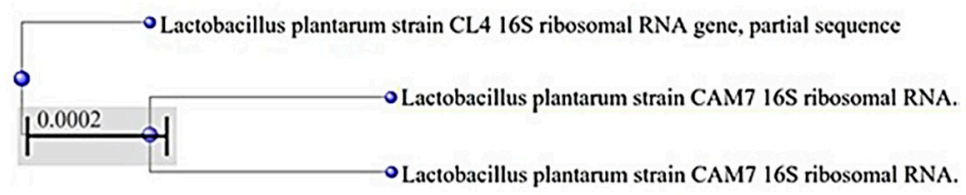

Figure 1. Phylogenetic tree of CAM6, CAM7, and CL4. This distance gives us a $0.0002 \%$ dissimilarity between the CL4 strain and the CAMs.

\subsection{Physiological Characteristics of the Lactic Acid Bacteria Isolates}

All three isolates tolerated $\mathrm{pH} 3$ and 4, and the CAM7 strain showed a significant reduction $(p<0.05)$ in growth at $\mathrm{pH} 5.6$ when compared to the CAM6 strain. Additionally, at pH 7, the CL4 strain showed a significant reduction $(p<0.05)$ in growth in comparison to the CAM6 strain, suggesting that the isolates have different $\mathrm{pH}$ sensitivities (Table 2). The inclusion of bile salts in MRS broth up to $0.15 \%$ stimulated the growth of the three stains. Nevertheless, for the highest concentration of bile salts $(0.30 \%)$, CAM6 showed better growth than CAM7 and CL4.

Table 2. In vitro assessment of functional properties of Lactobacillus spp. isolates from the native Zungo Pelado breed of pigs under various $\mathrm{pH}$, bile salt, sodium chloride $(\mathrm{NaCl})$, and temperature conditions $(n=3)$.

\begin{tabular}{|c|c|c|c|c|c|}
\hline \multirow{2}{*}{ Items } & \multicolumn{3}{|c|}{ Growth (Optical Density) of Lactobacillus Species } & \multirow{2}{*}{$\mathrm{SEM} \pm$} & \multirow{2}{*}{$p$ Value } \\
\hline & CAM6 & CAM7 & CL4 & & \\
\hline \multicolumn{6}{|c|}{$\mathrm{pH}$} \\
\hline 3 & 3.86 & 3.61 & 3.46 & 0.15 & 0.256 \\
\hline 4 & 3.71 & 3.45 & 3.64 & 0.13 & 0.403 \\
\hline 5.6 & $3.42^{\mathrm{a}}$ & $3.04^{\mathrm{b}}$ & $3.29 \mathrm{ab}$ & 0.09 & 0.006 \\
\hline 7 & $2.71^{\mathrm{a}}$ & $2.45^{\mathrm{ab}}$ & $2.14^{\mathrm{b}}$ & 0.09 & 0.014 \\
\hline \multicolumn{6}{|c|}{ Bile salts (\%) } \\
\hline 0.05 & 3.61 & 3.37 & 3.44 & 0.12 & 0.422 \\
\hline 0.10 & $2.75^{b}$ & $3.06^{\mathrm{ab}}$ & $3.28^{\mathrm{a}}$ & 0.09 & 0.019 \\
\hline 0.15 & 3.24 & 3.45 & 3.21 & 0.08 & 0.177 \\
\hline 0.30 & $2.81^{\mathrm{a}}$ & $2.71^{\mathrm{a}}$ & $2.44^{\mathrm{b}}$ & 0.05 & 0.006 \\
\hline \multicolumn{6}{|c|}{$\mathrm{NaCl}(\%)$} \\
\hline 2 & 3.21 & 3.44 & 3.33 & 0.17 & 0.670 \\
\hline 4 & $2.90^{b}$ & $3.35^{\mathrm{a}}$ & $3.31^{\mathrm{a}}$ & 0.08 & 0.015 \\
\hline 7 & $2.54^{b}$ & $3.23^{\mathrm{a}}$ & $2.12^{\mathrm{c}}$ & 0.10 & 0.001 \\
\hline 10 & $1.72^{\mathrm{a}}$ & $1.12^{b}$ & $0.85^{b}$ & 0.12 & 0.006 \\
\hline \multicolumn{6}{|c|}{ Temperature $\left({ }^{\circ} \mathrm{C}\right)$} \\
\hline 30 & 3.70 & 3.38 & 3.52 & 0.18 & 0.506 \\
\hline 37 & 3.57 & 3.48 & 3.51 & 0.17 & 0.935 \\
\hline 42 & 2.47 & 2.89 & 2.86 & 0.14 & 0.136 \\
\hline
\end{tabular}

$\mathrm{a}, \mathrm{b}, \mathrm{c}$ Means within rows with different superscript letters are significantly different at $p<0.05 ; n=3$. SEM: Standard
error of the mean. 
The strains isolated from Zungo Pelado pigs were tolerant to high salt concentrations. All strains grew in $\mathrm{NaCl}$ concentrations up to $10 \%$. While the CAM7 strain showed the highest growth at concentrations of up to $7 \% \mathrm{NaCl}(p<0.05)$, the CAM6 strain reached the highest level of growth at $10 \%$ bile salts. The incubation temperatures tested in our experiment did not modify the growth of Lactobacillus plantarum between groups $(p>0.05)$.

\subsection{Assessment of Antimicrobial Activity of the Lactic Acid Bacteria Isolates}

It was observed that all three selected isolates showed antagonistic activity against the different pathogens tested, except CAM7 for Escherichia coli and CL4 for Klebsiella pneumoniae. Specifically, L. plantarum CAM6 displayed the highest antagonistic activity against E. coli $(19.7 \mathrm{~mm})$ and S. enterica serovar Typhimurium (7.09 mm). Inhibition was also found for bacteria considered opportunistic, namely Klebsiella pneumoniae $(8.20 \mathrm{~mm})$ and Pseudomonas aeruginosa $(9.90 \mathrm{~mm})$ (Table 3).

Table 3. In vitro screening of antibacterial activity of Lactobacillus spp. isolates from the native Zungo Pelado breed of pigs against enteropathogenic bacteria $(n=3)$.

\begin{tabular}{cccc}
\hline \multirow{2}{*}{ Pathogenic Bacteria } & \multicolumn{3}{c}{ Inhibition Halo $(\mathbf{m m})$} \\
\cline { 2 - 4 } & CAM6 & CAM7 & CL4 \\
\hline E. coli strain NBRC 102203 & 19.7 & 0 & 6.9 \\
S. enterica serovar Typhimurium 4.5.12 & 7.1 & 6.2 & 7.9 \\
Klebsiella pneumoniae ATCC BAA-1705D-5 & 8.2 & 6.3 & 0 \\
Pseudomonas aeruginosa ATCC 15442 & 9.9 & 9.7 & 7.3 \\
\hline
\end{tabular}

\subsection{Evaluation of the Lactic Acid Bacteria Isolates on Antibiotic Sensitivity Test}

Selected strains were analyzed for their susceptibility to five antibiotics commonly used in the swine industry (Table 4). The three bacterial strains isolated from the Colombian native pig showed resistance to the antibiotics such as ciprofloxacin, tetracycline, doxycycline, and trimethoprim/ sulfamethoxazole, with the singular exception of the CAM6 strain showing intermediate resistance to trimethoprim/sulfamethoxazole. However, all LAB strains were susceptible to amoxicillin.

Table 4. Evaluation of the antibiotic sensitivity of the Lactobacillus spp. isolates from the native Zungo Pelado breed of pigs $(n=3)$.

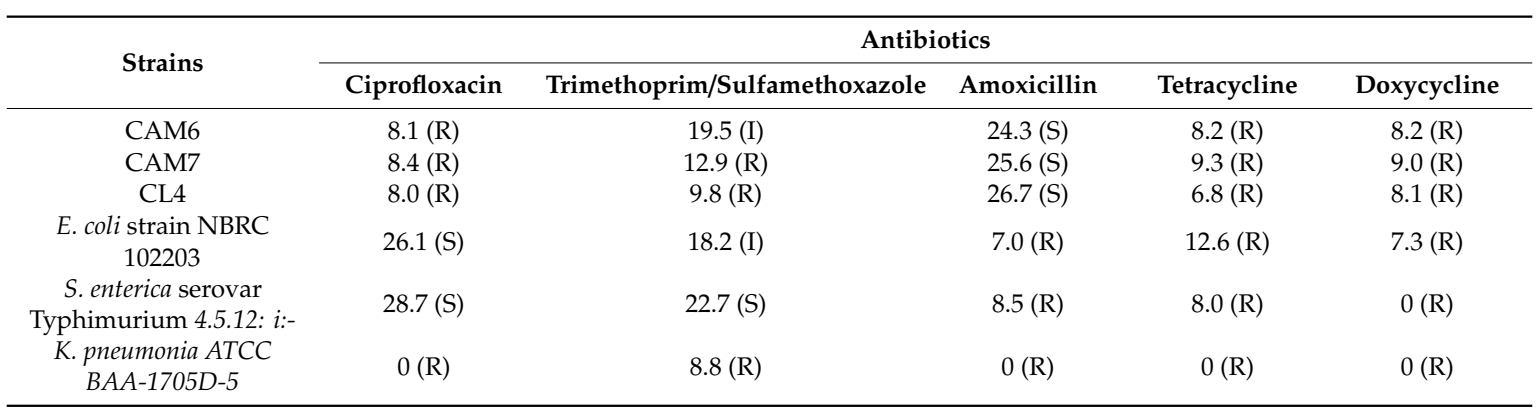

Inhibition halo (mm) for each antibiotic was measured: $\geq 21 \mathrm{~mm}$, susceptible (S); $16-20 \mathrm{~mm}$, intermediate (I); $\leq 15$ $\mathrm{mm}$, resistant $(\mathrm{R})$.

\section{Discussion}

The objective of this study was to demonstrate whether LAB isolated from Colombian Creole pigs could be suitable probiotic candidates according to their in vitro characteristics. From a total of nine initial strains (before laboratory tests), only three viable strains were available at the beginning of the physiological characterization. They were Gram-positive/rod-shaped coccobacilli that were catalaseand oxidase-negative, confirming that they belonged to the LAB group. 
The most common techniques we use to identify many facultative anaerobes are biochemical analyses, but these methods can yield varying results. In this study, we noted that biochemical characterization was not a more reliable identification approach despite being used as a primary method. For this reason, a molecular identification was necessary; in our case, all the strains were identified as Lactobacillus plantarum. Hence, genotypic systems are becoming valuable tools for use in studying a wide variety of microorganisms because they rely on comparisons of $16 \mathrm{~S}$ rRNA sequences from unknown bacteria, are not sensitive to variable culture conditions, and provide more consistent results than the current standard microbial techniques [34].

However, issues with and limitations of this method have been observed. Species identification is based on the comparison of specific sequence homology with a known catalogue generated from previously identified organisms through conventional methodologies [35]. The leading molecular technology currently available for microbial identification is the sequence analysis of $16 \mathrm{~S} \mathrm{rRNA}$, despite the availability of many new experimental molecular techniques for identification and the known problem of database accuracy and consistency over time [36]. These bacterial strains have been studied for their ability to form biofilms, a physical barrier that protects them from adverse environmental conditions [37] and makes them viable probiotic candidates for encapsulation.

Acid and bile salt tolerance are among the most important criteria for probiotic strain selection. All three isolates tolerated both $\mathrm{pH} 3$ and 7. Interestingly, even though $16 \mathrm{~S}$ rRNA identification showed the same identification profile, the isolates showed different growth rates in response to $\mathrm{pH}$. Lactic acid bacteria are generally acidophilic, which means they are tolerant to low $\mathrm{pH}$. In a condition of high free acid concentration $(\mathrm{H}+)$, free acids may cause growth inhibition [38]. Probiotic bacteria need to survive the passage through the stomach, where a pH of between 1.5 and 2.0 can be found [6], and into the intestinal tract [39].

Probiotic strains need to be tolerant to bile salts [1], and all three candidates showed good resistance up to a $0.15 \%$ concentration. In general, tolerance to bile salts is considered a condition for colonization and metabolic activity of bacteria in the host's intestine. Consequently, when evaluating the potential use of LAB as a probiotic, it is important to evaluate their ability to tolerate bile salts [40]. The average concentration of bile salts in the small intestine is around 0.2 to $0.3 \%$ and may go up to $2 \%$ $(w / v)$, depending upon the individual host and the type and amount of food ingested [41].

All strains were tolerant to high salt concentrations (up to $2 \%$ ). These results suggest that the evaluated strains can withstand higher concentrations of $\mathrm{NaCl}$ without losing their growth capacity, which suggests that they can be used in starter crops in the dairy industry, as preservatives of meat and vegetables, and as probiotics [42].

The growth of the strains at $40{ }^{\circ} \mathrm{C}$ demonstrates the ability of these microorganisms to grow at extreme temperatures. Bacteria that exhibit this characteristic show higher growth rates and can proliferate in the gastrointestinal tract, where the temperature is higher than $37^{\circ} \mathrm{C}$ [43]. Moreover, a high fermentation temperature reduces contamination by other microorganisms [44]. In addition, the capability of bacteria to grow at high temperatures is a favorable feature, allowing their use in technological procedures where high temperatures are applied [45].

E.coli and S. enterica serovar Typhimurium are the most commonly encountered pathogens in piglets responsible for neonatal diarrhea [46]. Antagonistic activity of L. plantarum against E. coli and Salmonella spp. in swine isolate was shown by Vera et al. [47]. Our results showed that the evaluated strains exerted antimicrobial activity, inhibiting microorganisms that are potentially pathogenic for animals. This inhibitory activity may be from the increase of primary metabolites such as ethanol, lactic acid, and carbon dioxide and the production of other antimicrobial compounds such as bacteriocins [31,48].

All isolates were resistant to ciprofloxacin, trimethoprim/sulfamethoxazole, tetracycline, and doxycycline but susceptible to amoxicillin. These results are in agreement with those of Jurado et al. [49], who also found sensitivity to penicillin in L. plantarum. Similarly, according 
to Shazali et al. [50], LAB isolated from broiler feces were found to be sensitive to penicillin and amoxicillin and resistant to ciprofloxacin and tetracycline.

Susceptibility to antimicrobial substances is an extremely vital selection property for a probiotic because this determines whether it can be coadministered with food supplements that contain antibiotics [51]. The high intrinsic resistance and susceptibility of microorganisms with probiotic activity to a range of antibiotics are quite significant. Since antibiotic resistance genes are generally carried by conjugative plasmids, they can be transferred to other bacteria [52], possibly resulting in antibiotic-resistant enteropathogenic bacteria. Therefore, it is also crucial to determine whether antibiotic resistance genes are present in chromosomes or plasmids [53].

\section{Conclusions}

In this study, the LAB isolates from the native Zungo Pelado breed of pigs showed good growth in response to $\mathrm{pH} 3.0$ and higher concentrations $(0.30 \%)$ of bile salts. In addition, the isolates possessed other desirable probiotic characteristics like tolerance to high $\mathrm{NaCl}$ concentrations ( 2 to $10 \%$ ) and different temperatures $\left(30,37\right.$, and $\left.42{ }^{\circ} \mathrm{C}\right)$. The isolated strains inhibited the in vitro growth of most of the pathogenic Enterobacteriaceae tested and were resistant to the presence of the antibiotics tested (except for CAM6, which showed intermediate resistance to trimethoprim/sulfamethoxazole), and all strains were susceptible to amoxicillin. The production of antibacterial compounds by these strains is an important characteristic to be studied later. The isolate CAM6, identified as Lactobacillus plantarum, showed consistent superiority over other isolates. Further studies to evaluate the effects of these probiotic candidate strains in commercial pigs are currently underway.

Author Contributions: Conceptualization, C.B. and Y.M.; methodology, C.B., G.T.-I., and Y.M.; software, G.T.-I.; validation, C.B., Y.M., and G.T.-I.; formal analysis, M.C.A. and B.V.-M.; investigation, C.B. and Y.M.; resources, C.B. and G.T.-I.; data curation, C.B. and Y.M.; writing-original draft preparation, C.B., Y.M., G.T.-I., M.C.A., and B.V.-M.; writing-review and editing, C.B., Y.M., G.T.-I., M.C.A., and B.V.-M.; funding acquisition, C.B., G.T.-I., and B.V.-M. All authors have read and agreed to the published version of the manuscript.

Funding: This work was supported by the University of Cordoba, Colombia under grant agreement number FCB-06-16.

Acknowledgments: This study was supported by University of Córdoba, Colombia, Grant No. FINV-011. The authors would like to extend their sincere appreciation to the specialists and technicians and very special acknowledgement to the late Cecilia Lara of the GRUBIODEQ group, Faculty of Sciences, University of Córdoba, Colombia.

Conflicts of Interest: The authors declare no conflict of interest.

\section{References}

1. Sirichokchatchawan, W.; Pupa, P.; Praechansri, P.; Am-in, N.; Tanasupawat, S. Autochthonous lactic acid bacteria isolated from pig faeces in Thailand show probiotic properties and antibacterial activity against enteric pathogenic bacteria. Microb. Pathog. 2018, 119, 208-215. [CrossRef]

2. Long, S.F.; Xu, Y.T.; Pan, L.; Wang, Q.; Wang, C.L.; Wu, J.Y.; Piao, X.S. Mixed organic acids as antibiotic substitutes improve performance, serum immunity, intestinal morphology and microbiota for weaned piglets. Anim. Feed Sci. Tech. 2018, 235, 23-32. [CrossRef]

3. Zeng, X.; Lin, J. Factors influencing horizontal gene transfer in the intestine. Anim. Health Res. Rev. 2017, 18, 153-159. [CrossRef]

4. Diraviyam, T.; Zhao, B.; Wang, Y.; Schade, R.; Michael, A.; Zhang, X. Effect of Chicken Egg Yolk Antibodies (IgY) against Diarrhea in Domesticated Animals: A Systematic Review and Meta-Analysis. PLoS ONE. 2014, 9, 97716. [CrossRef]

5. Wu, Z. Balancing food security and AMR. A review of economic literature on antimicrobial use in food animal production. China Agric. Econ. Rev. 2017, 9, 14-31. [CrossRef]

6. He, T.; Zhu, Y.H.; Yu, J.; Xia, B.; Liu, X. Lactobacillus johnsonii L531 reduces pathogen load and helps maintain short-chain fatty acid levels in the intestines of pigs challenged with Salmonella enterica Infantis. Vet. Microbiol. 2019, 230, 187-194. [CrossRef] 
7. Liu, G.; Aguilar, Y.M.; Zhang, L.; Ren, W.; Chen, S. Dietary supplementation with sanguinarine enhances serum metabolites and antibodies in growing pigs. J. Anim. Sci. 2016, 94, 75-78. [CrossRef]

8. Unterweger, C.; Kahler, A.; Gerlach, G.F.; Viehmann, M.; Von Altrock, A. Administration of non-pathogenic isolates of Escherichia coli and Clostridium perfringens type A to piglets in a herd affected with a high incidence of neonatal diarrhoea. Animal 2017, 11, 670-676. [CrossRef]

9. Unterweger, C.; Schwarz, L.; Viehmann, M.; von Altrock, A.; Gerlach, G.F. Treatment with probiotic bacteria does Not Diminish the impact of a Cystoisospora suis challenge in suckling piglets. Front. Vet. Sci. 2018, 5, 1-9. [CrossRef]

10. De Mille, C.M.; Curry, S.M.; Gabler, N.K.; Kerr, B.J. Effect of prebiotic, fatty acid and copper and zinc ingredients on nursery pig performance. J. Anim. Sci. 2018, 96, 156-157. [CrossRef]

11. Chen, J.; Kang, B.; Zhao, Y.; Yao, K.; Fu, C. Effects of natural dietary supplementation with Macleaya cordata extract containing sanguinarine on growth performance and gut health of early-weaned piglets. J. Anim. Physiol. Anim. Nutr. 2018, 102, 1666-1674. [CrossRef] [PubMed]

12. Julio-Gonzalez, L.C.; Hernandez-Hernandez, O.; Moreno, F.J.; Olano, A.; Jimeno, M.L. Trans- $\beta$-galactosidase activity of pig enzymes embedded in the small intestinal brush border membrane vesicles. Sci. Rep. $2019,9$. [CrossRef] [PubMed]

13. Xu, X.; Wang, H.L.; Li, P.; Zeng, Z.K.; Tian, Q.Y.; Piao, X.S.; Kuang, E.Y.W. A comparison of the nutritional value of organic-acid preserved corn and heat-dried corn for pigs. Anim. Feed Sci. Tech. 2016, 214, 95-103. [CrossRef]

14. Zeng, Z.; Zhang, S.; Wang, H.; Piao, X. Essential oil and aromatic plants as feed additives in non-ruminant nutrition: A review. J. Anim. Sci. Biotechnol. 2015, 6, 7. [CrossRef]

15. Liu, J.B.; Cao, S.C.; Liu, J.; Xie, Y.N.; Zhang, H.F. Effect of probiotics and xylo-oligosaccharide supplementation on nutrient digestibility, intestinal health and noxious gas emission in weanling pigs. Asian Australas. J. Anim. Sci. 2018, 31, 1660-1669. [CrossRef]

16. Liu, W.; Devi, S.; Park, J.; Kim, I. Effects of complex probiotic supplementation in growing pig diets with and without palm kernel expellers on growth performance, nutrient digestibility, blood parameters, fecal microbial shedding and noxious gas emission. Anim. Sci. J. 2018, 89, 552-560. [CrossRef]

17. Patarapreecha, P.; Jaikan, W.; Juangsaman, A.; Khajarern, J. Effects of dietary Bacillus subtilis supplementation as probiotics on growth performance and nutrients digestibility in fattening pigs. Pak. J. Nutr. 2018, 17, 634-640.

18. Shawk, D.J.; Feehan, B.J.; Harrison, O.L.; Woodworth, J.C.; Tokach, M.D. Effects of antimicrobial or probiotics on growth performance of 6 to $25 \mathrm{~kg}$ nursery pigs. J. Anim. Sci. 2018, 96, 114-115. [CrossRef]

19. Liao, S.F.; Nyachoti, M. Using probiotics to improve swine gut health and nutrient utilization. Anim. Nutr. 2017, 3, 331-343. [CrossRef]

20. Yang, X.; Jiang, Z.; Qiu, Y.; Wang, L. Effects of probiotic solid-state fermented complete feed on growth performance and pork quality of finishing pigs. J. Anim. Sci. 2018, 96, 232. [CrossRef]

21. Patel, S.; Shukla, R.; Goyal, A. Probiotics in valorization of innate immunity across various animal models. J. Funct. Foods 2015, 14, 549-561. [CrossRef]

22. Ma, T.; Suzuki, Y.; Guan, L.L. Dissect the mode of action of probiotics in affecting host-microbial interactions and immunity in food producing animals. Vet. Immunol. Immunopathol. 2018, 205, 35-48. [CrossRef]

23. Azad, M.A.K.; Sarker, M.; Wan, D. Immunomodulatory effects of probiotics on cytokine profiles. Biomed. Res. Int. 2018, 2018, 1-10. [CrossRef] [PubMed]

24. Kleniewska, P.; Pawliczak, R. Influence of synbiotics on selected oxidative stress parameters. Oxidative Med. Cell. Longev. 2017, 2017, 1-8. [CrossRef]

25. Roselli, M.; Pieper, R.; Rogel-Gaillard, C.; de Vries, H.; Bailey, M. Immunomodulating effects of probiotics for microbiota modulation, gut health and disease resistance in pigs. Anim. Feed Sci. Technol. 2017, 233, 104-119. [CrossRef]

26. Dowarah, R.; Verma, A.K.; Agarwal, N.; Singh, P. Efficacy of species-specific probiotic Pediococcus acidilactici FT28 on blood biochemical profile, carcass traits and physicochemical properties of meat in fattening pigs. Res. Vet. Sci. 2018, 117, 60-64. [CrossRef]

27. Chiang, M.L.; Chen, H.C.; Chen, K.N.; Lin, Y.C.; Lin, Y.T. Optimizing production of two potential probiotic Lactobacilli strains isolated from piglet feces as feed additives for weaned piglets. Asian Australas. J. Anim. 2015, 28, 1163-1170. [CrossRef] 
28. Qiao, J.; Li, H.; Wang, Z. Effects of Lactobacillus acidophilus dietary supplementation on the performance, intestinal barrier function, rectal microflora and serum immune function in weaned piglets challenged with Escherichia coli lipopolysaccharide. Antonie van Leeuwenhoek 2015, 107, 883-891. [CrossRef]

29. Wang, J.; Ji, H.; Wang, S.; Liu, H.; Zhang, W.; Zhang, D.; Wang, Y. Probiotic Lactobacillus plantarum Promotes Intestinal Barrier Function by Strengthening the Epithelium and Modulating Gut Microbiota. Front. Microbiol. 2018, 9, 1953. [CrossRef]

30. Altschul, S.F.; Gish, W.; Miller, W.; Myers, E.W.; Lipman, D.J. Basic local alignment search tool. J. Mol. Biol. 1990, 215, 403-410. [CrossRef]

31. Latorre, J.D.; Hernandez-Velasco, X.; Kuttappan, V.A.; Wolfenden, R.E.; Vicente, J.L. Selection of Bacillus spp. for cellulase and xylanase production as direct-fed microbials to reduce digesta viscosity and Clostridium perfringens proliferation using an In vitro digestive model in different poultry diets. Front. Vet. Sci. 2015, 2,1-8. [CrossRef] [PubMed]

32. Jorgensen, J.H.; Turnidge, J.D. Susceptibility Test Methods: Dilution and Disk Diffusion Methods. In Manual of Clinical Microbiology, 11th ed.; American Society of Microbiology: Washington, DC, USA, 2015; pp. 1253-1273.

33. Vlková, E.; Rada, V.; Popelářová, P.; Trojanová, I.; Killer, J. Antimicrobial susceptibility of bifidobacteria isolated from gastrointestinal tract of calves. Livest. Sci. 2006, 105, 253-259. [CrossRef]

34. Huang, C.H.; Chang, M.T.; Huang, L.; Chu, W.S. The dnaJ gene as a molecular discriminator to differentiate among species and strain within the Lactobacillus casei group. Mol. Cell. Probes 2015, 29, 479-484. [CrossRef]

35. Brandt, K.; Barrangou, R. Using glycolysis enzyme sequences to inform Lactobacillus phylogeny. Microb. Genom. 2018, 4, 1-13. [CrossRef]

36. Ayala, D.I.; Chen, J.C.; Bugarel, M.; Loneragan, G.H.; den Bakker, H.C. Molecular detection and quantification of viable probiotic strains in animal feedstuffs using the commercial direct fed microbial Lactobacillus animalis NP51 as a model. J. Microbiol. Methods 2018, 149, 36-43. [CrossRef]

37. Kubota, H.; Senda, S.; Tokuda, H.; Uchiyama, H.; Nomura, N. Stress resistance of biofilm and planktonic Lactobacillus plantarum subsp. plantarum JCM 1149. Food Microbiol. 2009, 26, 592-597.

38. Ito, T.; Miyamoto, H.; Kumagai, Y.; Udagawa, M.; Shinmyo, T. Thermophile-fermented compost extract as a possible feed additive to enhance fecundity in the laying hen and pig: Modulation of gut metabolism. J. Biosci. Bioeng. 2016, 121, 659-664. [CrossRef]

39. Sayan, H.; Assavacheep, P.; Angkanaporn, K.; Assavacheep, A. Effect of Lactobacillus salivarius on growth performance, diarrhea incidence, fecal bacterial population and intestinal morphology of suckling pigs challenged with F4+ enterotoxigenic Escherichia coli. Asian Australas. J. Anim. Sci. 2018, 31, 1308-1314. [CrossRef]

40. Secher, T.; Kassem, S.; Benamar, M.; Bernard, I.; Boury, M. Oral administration of the probiotic strain Escherichia coli Nissle 1917 reduces susceptibility to neuroinflammation and repairs experimental autoimmune encephalomyelitis-induced intestinal barrier dysfunction. Front. Immunol. 2017, 8, 1-10.

41. Hu, P.L.; Yuan, Y.H.; Yue, T.L.; Guo, C.F. Bile acid patterns in commercially available oxgall powders used for the evaluation of the bile tolerance ability of potential probiotics. PLoS ONE. 2018, 13, e0192964. [CrossRef]

42. Gancel, F.; Dzierszinski, F.; Tailliez, R. Identification and characterization of Lactobacillus species isolated from fillets of vacuum-packed smoked and salted herring (Clupea harengus). J. Appl. Microbiol. 1997, 82, 722-728. [CrossRef]

43. Önal, D.D.; Sönmez, Ş.; Beyatli, Y. The effects of inulin as a prebiotic supplement and the synbiotic interactions of probiotics to improve oxalate degrading activity. Int. J. Food Sci. Technol. 2019, 54, 121-131. [CrossRef]

44. De Filippis, F.; Troise, A.D.; Vitaglione, P.; Ercolini, D. Different temperatures select distinctive acetic acid bacteria species and promotes organic acids production during Kombucha tea fermentation. Food Microbiol. 2018, 73, 11-16. [CrossRef] [PubMed]

45. Salminen, S.; Laine, M.; von Wright, A.; Vuopio-Varkila, 1.; Korhonen, T.; Mattila-Sandholm, T. Development of selection criteria for probiotic strains to assess their potential in functional foods: A nordic and european approach. Biosci. Microflora 1996, 15, 61-70. [CrossRef]

46. De Keyser, K.; Dierick, N.; Kanto, U.; Hongsapak, T.; Buyens, G. Medium chain glycerides affect gut morphology, immune and goblet cells in post-weaning piglets: In vitro fatty acid screening with Escherichia coli and in vivo consolidation with LPS challenge. J. Anim. Physiol. Anim. Nutr. 2019, 103, 221-230. [CrossRef] [PubMed] 
47. Vera, R.; Ormaza, J.; Muñoz, J.; Arteaga, F. Sánchez, Lactobacillus plantarum strains with probiotic potentials isolated from creole pigs. Rev. Salud. Anim. 2018, 40,1-12.

48. Menconi, A.; Kallapura, G.; Latorre, J.D.; Morgan, M.J.; Pumford, N.R. Effect of prebiotic, fatty acid and copper and zinc ingredients on nursery pig performance. Biosci. Microb. Food. 2014, H33, 25-30.

49. Jurado, G.H.; Aguirre, F.D.; Ramírez, T.C. Characterization of isolated probiotic bacteria of the large intestine of pigs as alternative to using antibiotics. Rev. MVZ Cordoba 2009, 14, 1723-1735.

50. Shazali, N.; Foo, H.L.; Loh, T.C.; Choe, D.W.; Abdul, R.R. Prevalence of antibiotic resistance in lactic acid bacteria isolated from the faeces of broiler chicken in Malaysia. Gut Pathog. 2014, 6, 1. [CrossRef]

51. Sharma, P.; Tomar, S.K.; Goswami, P.; Sangwan, V.; Singh, R. Antibiotic resistance among commercially available probiotics. Food Res. Int. 2014, 57, 176-195. [CrossRef]

52. Brilhante, M.; Perreten, V.; Donà, V. Multidrug resistance and multivirulence plasmids in enterotoxigenic and hybrid Shiga toxin-producing/enterotoxigenic Escherichia coli isolated from diarrheic pigs in Switzerland. Vet. J. 2019, 244, 60-68. [CrossRef] [PubMed]

53. Gama, J.A.; Zilhão, R.; Dionisio, F. Impact of plasmid interactions with the chromosome and other plasmids on the spread of antibiotic resistance. Plasmid 2018, 99, 82-88. [CrossRef] [PubMed]

(C) 2020 by the authors. Licensee MDPI, Basel, Switzerland. This article is an open access article distributed under the terms and conditions of the Creative Commons Attribution (CC BY) license (http://creativecommons.org/licenses/by/4.0/). 